\section{JAK PROBĚHLY PRVNÍ MĚSÍCE ZAVÁDĚNÍ} E-RECEPTU

\section{Štěpán Svačina}

\section{Anotace}

Pro další rozvoj Českého zdravotnictví je klíčový rozvoj e-Health. Dojde k zvýšení efektivity a k zvýšení bezpečnosti zdravotnictví. E-recept se tak poměrně neočekávaně stal prvním krokem tímto směrem. Přes mnoho problémů první měsíce využívání e-receptu ukázaly, že je to cesta správná.

\section{Klíčová slova}

e-Health, e-recept, bezpečí ve zdravotnictví, kvalita ve zdravotnictví

\section{1 Úvod}

Na počátku roku 2017 byla vládou přijata koncepce e-health v ČR připravená ministerstvem zdravotnictví, ve spolupráci s ČSZIVI ČLS JEP. Zde byla problematika e-receptu zařazena až $v$ druhé fázi. Překvapivě však byl e-recept poměrně živelně a násilně zaveden již od ledna 2018. V nedávném hodnocení tzv. EURO health consumer index $\mathrm{EHCl}$ se Česká republika dostala na vynikající 8. místo v Evropě. Hodnocení ovlivňuje například snadná dostupnost biologické léčby a endoprotéz. Výhodné jsou i nízké personální náklady. Neefektivní je vysoký počet návštěv u lékaře a evidentně Česká republika zaostává v oblasti e-health.

\section{Jak zavádění e- receptu proběhlo}

E-recept byl připraven SUKL a vyvtvořené programy jsou funkční. Lékaře nejvíce znepokojila problematika e-podpisu. Tu Ize nepochybně hodnotit jako zbytečnou. Lékaře by šlo identifikovat mnohem snáze a zbytečné platby za e-podpis lékaře znepokojují. Trvale musí přenášet flash s podpisem, pokud pracují na různých místech. Lékaři zavedení e-podpisu a funkčního softwaru dlouho odkládali a potvrzování identity lékaře ČLK probíhalo pomalu a mnoho lékařů nemělo k 1. 1. 2018 e-podpis a nainstalovaný software.

Otázky připojení byly ponechány na lékaři. Lze přitom konstatovat, že funkční mobilní sítě neexistují na mnoha místech, kde je poskytována lékařská péče. Zde nepochybně selhává role státu, který používání e-preskripce vyhlásil.

Využití e-receptu Ize od 1. 1. 2018 rozdělit na několik kategorií.

1. Bezproblémové využití e-receptu.

2. Funkční e-recept s výrazným zdržováním lékaře v práci.

3. Nefunkční e-recept a pokračování v papírové preskripci.

Lékaři výrazně postrádají původně nabízené funkcionality problematiku interakcí, editaci lékového záznamu a tím zvýšení bezpečnosti pacienta ohroženého záměnami, dále informace o dostupnosti a cenách léků.

E-recept Ize tedy k 1. 1. 2018 hodnotit jako funkční, nepřinášející žádné benefity a zdržující.

\section{Jaké jsou perspektivy využití e-preskripce}

Zcela jistě je na prvním místě dosažení rychlejší funkčnosti a bezpečnosti preskripce, tedy nezdržování mnoha kliky, využití informace o předepsaných lécích, jejich cenách a jejich pro pacienta bezpečná editace.

Lékový záznam se musí stát klíčovou součástí zdravotnické dokumentace. Hodnotit tedy Ize, že e-recept je cesta správným směrem. Jeho provázanost $s$ dalším zdravotnickým softwarem je zatím bohužel malá. Již dnes však lékařům ukazuje, jakým směrem se elektronizace zdravotnictví bude vyvíjet a jak bezpečné zdravotnictví může být. 